\title{
Nutritional Composition and Sensory Acceptability of Stinging Nettle (Urtica simensis) Flour-Supplemented Unleavened Maize (Zea mays L.) Flatbread (Kitta)
}

\author{
Tona Zema Diddana $(\mathbb{D}$, Gezahegn Nigusse Kelkay, and Endale Elisho Tescha \\ School of Nutrition, Food Science and Technology, Hawassa University, Hawassa, Ethiopia \\ Correspondence should be addressed to Tona Zema Diddana; tonazema@gmail.com
}

Received 10 December 2020; Revised 1 June 2021; Accepted 4 August 2021; Published 14 August 2021

Academic Editor: Ivan Salmerón

Copyright (C) 2021 Tona Zema Diddana et al. This is an open access article distributed under the Creative Commons Attribution License, which permits unrestricted use, distribution, and reproduction in any medium, provided the original work is properly cited.

\begin{abstract}
In Ethiopia, a few studies had been conducted to improve the nutritional values and sensory acceptability of maize-based flatbread. These studies did not address indigenous edible wild green vegetables like stinging nettle (Urtica simensis). Consequently, there was a scientific report gap on the effect of incorporating stinging nettle leaf flour into local staple foods like flatbread. Therefore, this study was intended to investigate the nutritional composition and sensory acceptability of unleavened maize (Zea mays L.) flatbread (Kitta) supplemented with stinging nettle (Urtica simensis) flour. The flatbread was developed from composite flour of germinated maize and nettle leaf in a ratio of $90: 10,85: 15,80: 20$, and $75: 25$, respectively. Hundred percent (100\%) nongerminated maize flour flatbread was used as control. Proximate composition, minerals (Fe, $\mathrm{Zn}$, and $\mathrm{Ca}$ ), and vitamin $\mathrm{C}$ contents were analyzed. The sensory acceptability test was rated by a nine-point hedonic scale. The result revealed that crude protein and fat decreased from $11.02 \mathrm{~g}$ to $7.21 \mathrm{~g}$ and $1.12 \mathrm{~g}$ to $0.48 \mathrm{~g}$, respectively, when the amount of nettle flour supplementation increased from $0 \%$ to $25 \%$. On the contrary, total ash, crude fiber, and total carbohydrate slightly increased from 1.84 to $3.81 \mathrm{~g}, 2.19$ to 3.05 , and 75.53 to $80.05 \mathrm{~g}$, respectively. The calcium, zinc, and iron content significantly $(p<0.05)$ increased from 60.51 to $283.74 \mathrm{mg}, 5.09$ to $9.24 \mathrm{mg}$, and 1.72 to $3.59 \mathrm{mg}$ when the amount of nettle flour increased from $0 \%$ to $25 \%$, respectively. All sensory acceptability tests showed decrement with increasing the amount of nettle flour, but the control group has the highest acceptability.
\end{abstract}

\section{Introduction}

Unleavened flatbread, Kitta in local language (Amharic), is a baked product made from cereal flour [1]. It is made without adding baking powder and yeast. Flour and water are the two basic ingredients used to prepare unleavened flatbread. The flour comes from various types of cereals such as maize, wheat, rye, barley, teff, or their mixtures. Unleavened flatbread is consumed throughout the world although the recipe varies. In Ethiopia, it is instant bread usually prepared for immediate consumption or as a substitute of Injera. As a result, it is most commonly consumed traditional food in almost all rural communities and rarely by urban peoples [2].
A few studies had been conducted in Ethiopia to improve nutritional values and sensory acceptability of maize-based flatbread. For instance, Serka et al. [3] investigated the nutritional value and sensory acceptability of flatbread prepared from kocho, broad bean, and quality maize protein. Another study by Teferra et al. [4] also investigated the nutritional and sensory properties of flatbread from maize (Zea mays L.) and orange-fleshed sweet potato (Ipomoea batatas L.) flour. However, these studies done in Ethiopia were addressed indigenous edible wild green vegetables [5], such as stinging nettle (Urtica simensis). Some studies conducted outside Ethiopia, like Maietti et al. [6], investigated chemical composition and antioxidant performance in stinging nettle-supplemented breads. Similarly, Durovic et al. [7] also 
studied the effect of stinging nettle leaves and its extract enrichment of leavened bread. These studies focused on leavened bread with the addition of yeast. Moreover, these studies used white wheat as a recipe.

Stinging nettle (Urtica simensis) is an annual and perennial undervalued wild green herb distinguished by stinging hairs [8]. It is categorized under the genus Urtica of the family Urticaceae [1]. It mostly grows in temperate and tropical wasteland areas around the world. In Ethiopia, it grows in the highlands of the Amhara region around North and South Gondar, North and South Wollo, North Shewa, and Wag Hamra, Gojam; Oromia region around Kofole of Arsi zone and in most highlands of Sidama Zone in the southern region [9].

Stinging nettle (Urtica simensis) leaves are eaten in many parts of the world as cooked leaves at times of famine $[5,10$, 11]. The leaves are popular especially in poor countries and lower socioeconomic classes [12]. It could be utilized as spinach like a cooked vegetable in the human diet $[5,10,13,14]$. For instance, the leaf of nettle is used as a wild source of vegetables in rural areas of South Africa [13, 14], and some highland areas of Ethiopia $[11,15]$. Nettles may also be used as juice, tea, and an ingredient in many dishes [16]. This plant is endemic to Ethiopia and identified as one of the most commonly utilized wild edible plant species in some parts of the country [17]. In Ethiopia, the young nettle leaves mixing with barley powder are utilized as side dishes such as soup and served with Injera and cooked during fasting and famine or food shortage season [18].

Stinging nettle (Urtica simensis) leaves add not only variety to the menu but also valuable sources of macro- and micronutrients and other bioactive compounds. Hughes et al. [19] reported that the essential amino acids in nettle are comparable to beans (Phaseolus vulgaris) and chicken (Gallus gallus). Amino acids from dehydrated nettle meal are also nutritionally better compared to alfalfa meal [9]. Another study revealed that nettle leaf powder contained higher protein compared to wheat and barley flours [20]. The fresh nettle leaves are rich in $\mathrm{Ca}$ and iron [18, 21], zinc [22], previtamin A [23], protein and vitamin A [18, 23], and ascorbic acid (vitamin C) [18, 24].

Utilizing such wild edible plants may help to close food gaps during famine and combat food insecurity concomitantly improving malnutrition in low-income countries. However, there is a limited scientific report on the effect of incorporating nettle leaves on the chemical composition and sensory acceptability of unleavened flatbread in Ethiopia. On the other hand, this plant is considered as poor man's food [18], weeds due to their rapid growth and soil coverage [16], and undervalued plant. Considering this scientific report gap and valuable nutritional and nutrient contribution of the nettle, this study was intended to investigate the nutritional composition and sensory acceptability of unleavened flatbread (Kitta) developed from stinging nettle (Urtica simensis) leaf and maize (Zea mays L.) flour.

\section{Materials and Methods}

2.1. Sample Preparation. Maize (Zea mays L.) and stinging nettle (Urtica simensis) were procured from Hawassa town open market and Wondogenet district, respectively. Maize was sorted, cleaned, and then soaked for $24 \mathrm{hrs}$ in clean water. The soaked maize was rinsed with clean tap water. Then, it was allowed to germinate for $48 \mathrm{hrs}$ and sun-dried. The young shoot of the nettle (Uritca simensis) leaf was separated from its steam using sanitized protective gloves. The leaves were washed by deionized water and then dried at room temperature in the food processing laboratory of the Department of Food Science and Technology Hawassa University, Ethiopia. Finally, the dried control maize, germinated maize (treatment recipes), and young shoot of nettle leaves were separately milled into flour passing a $1 \mathrm{~mm}$ diameter sieve using a laboratory miller (Thomas Wiley Mill Model 4 , USA). The sieved flour was packed in a polyethylene bag and stored at room temperature until flatbread preparation.

2.2. Blending Ratio and Flatbread Preparation. Five treatments (SN0, SN10, SN15, SN20, and SN25) were formulated from nongerminated traditional maize flour (control), germinated maize flour, and nettle leaf flour as depicted in Table 1. The dough of the control group and treatment group was prepared by mixing the blended flour and water. The dough was manually kneaded until it became soft. The softened and smooth dough was wrapped by enset leaves (Enset ventricosum). Then, it was baked by a preheated local clay griddle called "Mitad" for 15-20 minutes. The baked flatbread was milled into flour. Finally, the flour was packed in a polyethylene bag and kept in desiccators until compositional analysis.

2.3. Nutritional Composition Analysis. The chemical composition of the flatbread was analyzed in the Ethiopian Public Health Institute (EPHI) food analysis laboratory, Addis Ababa. Proximate compositions (crude protein, moisture, crude fat, crude fiber, and total ash), vitamin $\mathrm{C}$, and minerals (calcium, zinc, and iron) were analyzed by the methods of the Association of Official Analytical Chemists (AOAC) [25]. Vitamin C was analyzed by UV spectrophotometer Shimadzu (Model: UV-1800).

2.4. Determination of Moisture Content. Moisture content was determined by drying the samples in a drying oven (Memmert, Din 40050, West Germany). Empty dishes and lids (made of porcelain) were dried at $100^{\circ} \mathrm{C}$ for $1 \mathrm{hr}$. The dried dishes were then transferred to the desiccators which contain granular silica gel and cooled for 30 minutes. The dried empty dishes were weighed $\left(\mathbf{W}_{1}\right)$. About $3.00 \mathrm{~g}$ of fresh sample were thoroughly mixed and transferred to the dried and weighed dishes. Then, dishes and their contents were weighed $\left(\mathbf{W}_{2}\right)$. The contents were placed in the drying oven and dried for $3 \mathrm{hr}$ at $105^{\circ} \mathrm{C}$. Finally, the dishes and their contents were cooled in a desecrator to room temperature and reweighed $\left(\mathbf{W}_{3}\right)$. The moisture contents of the sample were determined and expressed as follows:

$$
\text { Moisture }(\%)=\frac{\left(W_{2}-W_{1}\right) * 100}{W_{2}-W_{1}},
$$


TABLE 1: Treatment blending ratio of nongerminated maize (NGM) flour, germinated maize (GM) flour, and nettle (Urtica simensis) flour.

\begin{tabular}{lccc}
\hline Treatments & Nongerminated maize flour (NGMF) & $\begin{array}{c}\text { Blending ratio } \\
\text { Germinated maize flour (GMF) }\end{array}$ & Stinging nettle (Urtica Simensis) flour (SN) \\
\hline SN0 & $100 \%$ & - & - \\
SN10 & - & $90 \%$ & $10 \%$ \\
SN15 & - & $85 \%$ & $15 \%$ \\
SN20 & - & $80 \%$ & $20 \%$ \\
SN25 & & $75 \%$ & $25 \%$ \\
\hline
\end{tabular}

SN0 $=100 \%$ nongerminated maize flour (control); SN10 = 90\% germinated maize flour $+10 \%$ nettle flour; SN15 = $85 \%$ germinated maize flour $+15 \%$ nettle flour; SN20 = 80\% germinated maize flour $+20 \%$ nettle flour; SN25 = 75\% germinated maize flour $+25 \%$ nettle flour.

where $W_{1}$ is the weight of empty dish (g), $W_{2}$ is the weight of empty dish + fresh sample before drying (g), $W_{2}$ - $W_{1}$ is the weight of sample $(\mathrm{g}), W_{3}$ is the weight of container + sample after drying $(\mathrm{g})$, and $W_{2}-W_{3}$ is the loss of weight (g).

2.5. Determination of Crude Protein Content. Crude protein was analyzed by the Kjeldahl method using the Kjeldahl analyzer in three steps (digestion, titration, and distillation). Digestion, step 1: initially, the sample was homogenized and then $2.00 \mathrm{~g}$ of fresh samples was taken in a Tecator tube. Concentrated orthophosphoric acid and concentrated sulfuric acid in ratio $5: 100$, respectively, were added and mixed thoroughly. A $3.5 \mathrm{ml}$ of $30 \%$ hydrogen peroxide was added step by step. Immediately after the violent reaction had ended, the tubes were shaken and placed back to the rack. Three grams of catalyst, a mixture of ground $0.5 \mathrm{~g}$ of selenium metal with $100 \mathrm{~g}$ of potassium sulfate was added into each tube and allowed to stand for about 10 minutes before digestion. Then, the tubes were lowered into protein digester when the temperature of the digester attained $370^{\circ} \mathrm{C}$. The digestion was continued for about 1 hour until a clear solution was obtained. The tubes in the rack were cooled in a fume hood; $15 \mathrm{ml}$ of deionized water was added and shaken to avoid precipitation of sulfate in the solution. Distillation, step 2: the digested and diluted sample solution was distilled using boric acid. Titration, step 3: the distillate was titrated using $0.1 \mathrm{~N}$ sulfuric acid to reddish color using the Kjeldehal apparatus (Kjeltec 2300 Analyzer unit, Foss Tecator AB, Hoganas, Sweden).

2.6. Determination of Crude Fat Content. The crude fat content was determined by exhaustively extracting a measured and known weight of sample in diethyl ether (boiling point $55^{\circ} \mathrm{C}$ ) in a soxhlet extractor (model: 2055 Soxtec Foss Tecator). The ether was evaporated from the extraction flask. The amount of fat was quantified gravimetrically and calculated from the difference in weight of extraction flask before and after extraction as percentage. The extraction flasks were cleaned, dried in a drying oven (Memmert, Germany) at $70^{\circ} \mathrm{C}$ for 1 hour, cooled in desiccators (with granular silica gel) for 30 minutes, and then weighed $\left(\mathbf{W}_{1}\right)$. The bottom of the extraction thimble was covered with about $2 \mathrm{~cm}$ layer of fat-free cotton. Two grams $\left(W_{\mathrm{o}}\right)$ of fresh sample was added into the extraction thimbles and then covered with about $2 \mathrm{~cm}$ layer of fat-free cotton. The thimbles with the sample content were placed into a Soxhlet extraction chamber. The cooling water was switched on, and a $50 \mathrm{ml}$ of diethyl ether was added to the extraction flask through the condenser. The extraction was conducted for about 3 hours. The extraction flasks with their content were removed from the extraction chamber and placed in the drying oven at $70^{\circ} \mathrm{C}$ for about one hour, cooled to room temperature in the desiccators for half an hour. The content was reweighed $\left(W_{2}\right)$ immediately after it was taken out of desiccators. The amount of crude fat in the sample was calculated by the difference in weight of the extraction flask before and after extraction shown as follows:

$$
\operatorname{Fat}(\%)=\frac{\left(W_{2}-W_{1}\right) * 100}{W_{\mathrm{o}}}
$$

where $W_{\mathrm{o}}$ is the weight of fresh sample, $W_{1}$ is the weight of dried flask, and $W_{2}$ is the weight of extraction flask after extraction (weight of flask and fat).

2.7. Determination of Crude Fiber Content. The crude fiber was determined in four steps (digestion, filtration, washing, and drying and combustion) using a muffle furnace (Model: Carbolite, England). Digestion, step 1: $2.00 \mathrm{~g}\left(W_{1}\right)$ of fresh sample was placed into a $600 \mathrm{ml}$ beaker, and $200 \mathrm{ml}$ of $1.25 \% \mathrm{H}_{2} \mathrm{SO}_{4}$ was added. The content was then gently boiled for 30 minutes placing a watch glass over the mouth of the beaker. After 30 minutes of boiling, $20 \mathrm{ml}$ of $28 \% \mathrm{KOH}$ was added and boiled gently for further 30 minutes with occasional stirring. Filtration, step 2: the bottom of sintered glass crucible was covered with a $10 \mathrm{~mm}$ sand layer, and the layer of the sand was wetted with a little distilled water. The solution was poured from the beaker into sintered glass crucible, and then, the vacuum pump was turned on. The wall of the beaker was rinsed with hot distilled water several times; washings were transferred to a crucible and filtered. Washing, step 3: the residue in the crucible was washed with hot distilled water and filtered. The residue was washed with $1 \% \mathrm{H}_{2} \mathrm{SO}_{4}$ and filtered and then washed with hot distilled water and filtered. Again, the residue was washed with $1 \%$ $\mathrm{NaOH}$ and filtered; again, it was washed with hot distilled water and filtered. Again, the residue was washed with 1\% $\mathrm{H}_{2} \mathrm{SO}_{4}$ and filtered; again, it was washed twice more with hot, distilled water and filtered. Finally, it was washed with water-free acetone. Drying and combustion, step 4: the crucible with its content was dried for 2 hours in an electric drying 
oven at $130^{\circ} \mathrm{C}$ and cooled for $30 \mathrm{~min}$ in the desiccators (with granular silica gel) and then weighed $\left(W_{2}\right)$. The crucible was transferred to a muffle furnace (Gallenkamp, model FSL 340$0100, \mathrm{UK})$ and incinerated for $30 \mathrm{~min}$ at $550^{\circ} \mathrm{C}$ for ashing. The crucible was cooled in the desiccators and weighed $\left(W_{3}\right)$. Then, the crude fiber was calculated as a residue after subtraction of the ash shown in the following formula:

$$
\text { Crude fiber }(\%)=\frac{\left(W_{2}-W_{1}\right) * 100}{W},
$$

where $W_{1}$ is the weight of crucible, sand, and residue; $W_{2}$ is the weight of crucible and sand; and $W$ is the sample weight.

2.8. Determination of Total Ash. Total ash was determined by ashing the sample at $550^{\circ} \mathrm{C}$ using a muffle furnace. Porcelain dishes were placed in a muffle furnace (Carbolite, Aston Lane, Hope, Sheffield, England, UK) for $30 \mathrm{~min}$ at $550^{\circ} \mathrm{C}$. The dishes were cooled in desiccators (with granular silica gel) for about 30 minutes and weighed to the nearest milligram $\left(W_{1}\right)$. About three grams of fresh sample in duplicate was placed in dishes $\left(W_{2}\right)$. The dishes were placed on a hot plate under a fume hood, the temperature was slowly increased until smoking ceases, and the samples become thoroughly charred. The dish with sample was placed inside the muffle furnace at $550^{\circ} \mathrm{C}$ for an hour and cooled in desiccators for 1 hour. The crucible was removed from the furnace and allowed to cool to room temperature. The cooled samples were moistened again with a few drops of deionized water and allowed to evaporate in a hot plate. Again, it was ashed at $550^{\circ} \mathrm{C}$ for 30 minutes and the crucible was allowed to cool; some drops of deionized water and 5 drops of concentrated $\mathrm{HNO}_{3}$ were added and evaporated. Again, the content was reached at $550^{\circ} \mathrm{C}$ for 30 minutes. When cooled to room temperature, each dish with ash was reweighed to the nearest milligram $\left(W_{3}\right)$. Then, the total ash was determined as follows:

$$
\operatorname{Ash}(\%)=\frac{\left(\mathrm{W}_{3}-\mathrm{W}_{1}\right) * 100}{\mathrm{~W}_{2}-\mathrm{W}_{1}}
$$

where $W_{1}$ is the weight of dried dish, $W_{2}$ is the weight of fresh sample and dried dish, and $W_{3}$ is the weight of dish and ash.

2.9. Determination of Total Carbohydrate. The total carbohydrate content was determined by difference (subtracting the moisture content, crude protein, total ash, and fat from the total dry weight of the sample).

$$
\begin{aligned}
\text { Carbohydrate }(\%)= & 100-(\text { fat }(\%)+\operatorname{protein}(\%) \\
& +\operatorname{ash}(\%)+\text { moisture }(\%)
\end{aligned}
$$

2.10. Determination of Total Gross Energy. Gross energy was determined by summing energy from fat, carbohydrate, and protein contents using Atwater's conversion factors considering protein and carbohydrate each gives $4 \mathrm{kcal}$ and fat yields $9 \mathrm{kcal}$ per 100 gram [26].

$$
\begin{array}{r}
\operatorname{Gross} \text { energy }(\mathrm{Kcal} / 100 \mathrm{~g})=9 * \text { fat }+4 * \text { protein } \\
+4 * \text { carbohydrate. }
\end{array}
$$

2.11. Determination of Total Minerals (Zinc, Iron, and Calcium). Minerals were determined using the Shimadzu atomic absorption spectrophotometer (Model: AAS6800). Crucibles were washed with $6 \mathrm{~N} \mathrm{HCl}$ and glasswares with $10 \%$ nitric acid. Then, the crucibles were placed in an oven for 30 minutes at $100^{\circ} \mathrm{C}$ and cooled in desiccators for 30 minutes. Then, $2.5 \mathrm{~g}$ of sample was weighed and charred at a hot plate starting from low temperature under a hood. Dry ashing, step 1: ashes were obtained by ashing samples in a muffle furnace at $550^{\circ} \mathrm{C}$ for 1 hour. The crucible was cooled and moistened with a few drops of deionized water, and water was evaporated on a hot plate. Again, the sample was ashed for 30 minutes at $550^{\circ} \mathrm{C}$ and cooled; a few drops of deionized water and 5 drops of concentrated $\mathrm{HNO}_{3}$ were added and allowed to evaporate on a hot plate. Finally, the sample was ashed once again for 30 minutes at $550^{\circ} \mathrm{C}$, the crucible was cooled in desiccators for 1 hour, and the content was weighed. Dissolution, step 2: the ash was treated with $5 \mathrm{ml}$ of $6 \mathrm{~N} \mathrm{HCl}$ to wet it completely and dried on a low temperature hot plate. $\mathrm{A} 7 \mathrm{ml}$ of $3 \mathrm{~N} \mathrm{HCl}$ was added to the dried ash and heated on the hot plate until the solution just boils. The ash solution was cooled to room temperature and filtered through a filter paper (Whatman 42, $125 \mathrm{~mm}$ ) into graduated flask. A $5 \mathrm{ml}$ of $3 \mathrm{~N} \mathrm{HCl}$ was added into each crucible dishes and heated until the solution just boiled, cooled, and filtered into the flask. The crucible dishes were again washed three times with deionized water; the washings were filtered into the flask. A $2.5 \mathrm{ml}$ of $10 \%$ lanthanum chloride solution was added into each graduated flask. Then, the solution was cooled and diluted to the mark $(50 \mathrm{ml})$ with deionized water. A blank was prepared by using the same procedure as the sample.

$$
\text { Minerals (iron, zinc, and calcium })(\mathrm{mg} / 100 \mathrm{~g})=\frac{[(a-b) * V]}{10 * W} \text {, }
$$

where $W$ is the weight (g) of samples; $V$ the volume (V) of extract; $a$ is the concentration $(\mu \mathrm{g} / \mathrm{ml})$ of sample solution; $b$ is the concentration $(\mu \mathrm{g} / \mathrm{ml})$ of blank solution.

2.12. Determination of Total Phytate. Phytate was determined by the method of Latta and Eskin (1980) and later modified by Vantraub and Lapteva [27]. About $0.1000 \mathrm{~g}$ of fresh samples was extracted with $10 \mathrm{ml} 2.4 \% \mathrm{HCl}$ in a mechanical shaker (Eberbach) for 1 hour at an ambient temperature and centrifuged at $3000 \mathrm{rpm}$ for 30 minutes. The clear supernatant was used for phytate estimation. A $2 \mathrm{ml}$ of Wade reagent (containing $0.03 \%$ solution of $\mathrm{FeCl}_{3} \cdot 6 \mathrm{H}_{2} \mathrm{O}$ and $0.3 \%$ of sulfosalicylic acid in water) was added to $3 \mathrm{ml}$ of the sample solution (supernatant), and the mixture was mixed on a Vortex (Maxi Maxi II) for 5 seconds. The absorbance of the sample solutions was measured at $500 \mathrm{~nm}$ using the UV-VIS spectrophotometer (Beckman DU-64-spectrophotometer, USA). A series of standard solutions were 
prepared containing $0,5,10,20$, and $40 \mu \mathrm{g} / \mathrm{ml}$ of phytic acid (analytical grade sodium phytate) in $0.2 \mathrm{~N} \mathrm{HCl}$. A $3 \mathrm{ml}$ of standard was added into $15 \mathrm{ml}$ of centrifuge tubes with $3 \mathrm{ml}$ of water which were used as a blank. A $1 \mathrm{ml}$ of the Wade reagent was added to each test tube, and the solution was mixed on a Vortex mixer for 5 seconds. The mixtures were centrifuged for 10 minutes, and the absorbance of the solutions (both the sample and standard) was measured at $500 \mathrm{~nm}$ by using deionized water as a blank. A standard curve was made from absorbance versus concentration, and the slope and intercept were used for calculation.

$$
\text { Phytate }(\mathrm{mg} / 100 \mathrm{~g})=\frac{(\text { Absorbance }- \text { Intercept }) * 3}{\text { Slope } * \rho * \text { weight of sample } * 10}
$$

where $\rho$ is density.

2.13. Determination of Phytic Acid to Mineral Ratio. The mole of phytate and minerals (zinc, iron, and calcium) was determined by dividing the weight of phytate and minerals with its atomic weight. The molar ratio between phytate and zinc was obtained after dividing the mole of phytate with the mole of minerals. Thus, the phytate zinc molar ratio was calculated using the following formula [28]:

Phytate to mineral ratio $=\frac{\text { phytic acid }(\mathrm{mg} / 100 \mathrm{~g}) / 660}{\text { minerals }(\mathrm{mg} / 100 \mathrm{~g}) / \text { atomic weight }}$.

2.14. Sensory Acceptability Tests. Flatbread transferred into identical plates coded with three-digit random numbers. Triplicate samples from the same treatments were served for the acceptability test. Taste, color, flavor, mouth fullness, appearance, and overall acceptance of flatbread samples were rated by 15 untrained panelists using a 9-point hedonic scale ( 9 = like extremely and $1=$ dislike extremely) [29, 30]. Finally, the rated sensory acceptability test scores were averaged.

2.15. Experimental Design and Statistical Analysis. Proximate composition, minerals, and vitamin $\mathrm{C}$ data were entered into a Statistical Package for the Social Sciences (SPSS) version 20 software program [31]. A completely randomized design (CRD) was used for nutritional composition data analysis. Randomized complete block design (RCBD) was used for sensory acceptability test to block error from between and within treatment and panelists. The significant mean differences of nutritional composition and sensory acceptability among groups were tested by one-way analysis of variance (ANOVA) and two-way ANOVA, respectively. Mean separation was done using the Tukey significance difference test at a $p$ value less than 0.05 . Finally, the result was described by means and standard deviation.

\section{Result}

3.1. Proximate Composition of Flatbread. The Proximate composition of the flatbread formulated from maize flour with diffrent levels of stinging nettle (Urtica simensis) is indi- cated in Table 2. The moisture content of the SN0 (control group) was significantly $(p<0.05)$ different from the treatment groups. As the proportion of nettle leaf flour increased, the moisture content slightly decreased from 10.68 in control to $8.44 \%$ in SN25 (25\% nettle leaf flour supplemented) flatbread. The crude protein content of the SN0 was not significantly different from SN10 (10\% supplemented bread), but it was different from SN15 (15\% nettle supplemented), SN20 (20\% nettle supplemented), and SN25. The value of crude protein showed a slight decrement with increasing the proportion of nettle flour supplement. The crude fat and total ash of the control group did not show a significant difference $(p>0.05)$ from SN10 and SN15, but it was significantly $(p<0.05)$ different from SN20 and SN25. Crude fat content decreased, and the total ash increased when the proportion of nettle flour supplement increased. Except for SN10, which did not show a difference, the crude fiber content of the control group (SN0) was significantly different from SN15, SN20, and SN25. The total carbohydrate value of SN0 was significantly different from all nettle flour-supplemented flatbread. Both crude fiber and total carbohydrate contents slightly increased with increasing the amount of nettle flour. The gross energy value of SN0 was not significantly $(p>0.05)$ different from nettle flour-supplemented flatbread.

3.2. Selected Minerals, Vitamin C Content, Phytic Acid, and Zinc to Phytate Molar Ratio. Table 3 depicts the values of selected minerals, vitamin $\mathrm{C}$, phytic acid, and zinc to phytate molar ratio. The minerals (calcium, iron, and zinc) and vitamin $C$ content showed a significant $(p<0.05)$ increment when the amount of nettle flour added increased. The calcium, iron, and zinc content increased by approximately 5 folds, 2 folds, and 2 folds in 25\% nettle flour-supplemented flatbread compared to the control group, respectively. Vitamin $\mathrm{C}$ was not detected in the control, but $12.61 \mu \mathrm{g}$, $23.99 \mu \mathrm{g}, 34.99 \mu \mathrm{g}$, and $47.57 \mu \mathrm{g}$ in $10 \%, 15 \%, 20 \%$, and $25 \%$ nettle flour supplemented flatbread, respectively. Regarding phytate, the numeric value of phytate slightly decreased (84.64-70.47 mg/100 g) when comparing the control and supplemented groups. However, the content showed increment within the treatment group. There was a significant difference $(p<0.05)$ in the phytate content of the control and treatment groups. Similarly, the phytate to the mineral molar ratio (phytate: zinc, phytate: iron, and phytate: calcium) was decreased when the proportion of nettle flour increased.

3.3. Sensory Acceptability. The result of sensory acceptability of the nettle flour-supplemented unleavened maize flatbread is depicted in Table 4 . The mean and standard deviation of all sensory quality parameters decreased with increasing the proportion of nettle flour. The control sample had the highest rating, and the treatment group rated from liked moderately to liked slightly except for the color which was neither liked nor disliked. There is a highly statistically significant difference $(p<0.05)$ between the color preference of control and the other four treatments. The taste and flavor of SN15 and SN20, the appearance of SN10, and the mouthfeel of SN10 and SN15 were not significantly $(p>0.05)$ different from the control group. All 


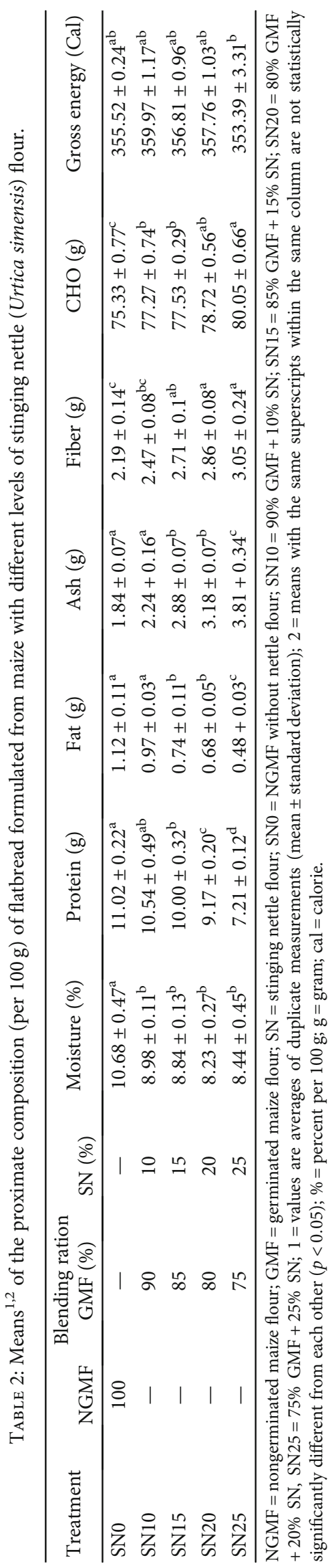




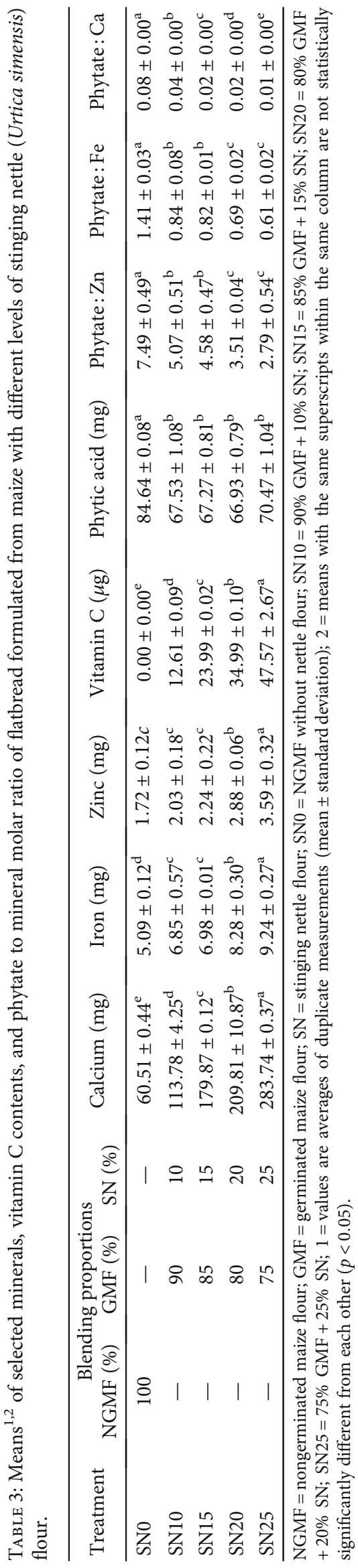


TABLE 4: Means ${ }^{1,2}$ of sensory acceptability scores of the flatbread developed from stinging nettle and maize flour performed at laboratory level.

\begin{tabular}{lccccccccc}
\hline \multirow{2}{*}{ Treatment } & \multicolumn{3}{c}{ Blending ratio } & \multicolumn{5}{c}{ Sensory attributes } \\
& NGMF & GMF & SN & Color & Taste & Flavor & Appearance & Mouthfeel & Overall acceptability \\
\hline SN0 & 100 & - & - & $8.71 \pm 0.25^{\mathrm{a}}$ & $8.22 \pm 0.23^{\mathrm{a}}$ & $8.71 \pm 0.26^{\mathrm{a}}$ & $8.73 \pm 0.23^{\mathrm{a}}$ & $8.58 \pm 0.10^{\mathrm{a}}$ & $8.59 \pm 0.02^{\mathrm{a}}$ \\
SN10 & - & 90 & 10 & $7.97 \pm 0.15^{\mathrm{b}}$ & $7.47 \pm 0.09^{\mathrm{b}}$ & $7.80 \pm 0.20^{\mathrm{b}}$ & $8.26 \pm 0.11^{\mathrm{ab}}$ & $8.11 \pm 0.12^{\mathrm{a}}$ & $7.92 \pm 0.09^{\mathrm{b}}$ \\
SN15 & - & 85 & 15 & $6.37 \pm 0.19^{\mathrm{c}}$ & $7.26 \pm 0.17^{\mathrm{bc}}$ & $7.56 \pm 0.18^{\mathrm{bc}}$ & $7.86 \pm 0.28^{\mathrm{bc}}$ & $7.89 \pm 0.22^{\mathrm{a}}$ & $7.59 \pm 0.10^{\mathrm{c}}$ \\
SN20 & - & 80 & 20 & $6.92 \pm 0.08^{\mathrm{cd}}$ & $6.93 \pm 0.25^{\mathrm{cd}}$ & $7.21 \pm 0.19^{\mathrm{cd}}$ & $7.31 \pm 0.09^{\mathrm{cd}}$ & $6.77 \pm 0.54^{\mathrm{b}}$ & $7.03 \pm 0.09^{\mathrm{d}}$ \\
SN25 & - & 75 & 25 & $5.61 \pm 0.11^{\mathrm{d}}$ & $6.45 \pm 0.20^{\mathrm{d}}$ & $6.73 \pm 0.21^{\mathrm{d}}$ & $6.87 \pm 0.26^{\mathrm{d}}$ & $6.57 \pm 0.50^{\mathrm{b}}$ & $6.65 \pm 0.02^{\mathrm{e}}$ \\
\hline
\end{tabular}

$\mathrm{NGMF}=$ nongerminated maize flour; GMF = germinated maize flour; SN = stinging nettle flour; SN0 = NGMF without nettle flour; SN10 = 90\% GMF + 10\% SN; SN15 $=85 \%$ GMF $+15 \%$ SN; SN20 $=80 \%$ GMF $+20 \%$ SN, SN25 $=75 \%$ GMF $+25 \%$ SN; $1=$ values are averages of triplicate measurements (mean \pm standard deviation) of 15 untrained panelists at laboratory level; $2=$ means with the same superscripts within the same column are not statistically significantly different from each other $(p<0.05)$.

the nettle leaf flour-supplemented flatbread was rated like very much at $10 \%$ supplementation.

\section{Discussion}

The result of proximate composition indicated that the moisture and crude protein contents of flatbread were slightly decreased with an increase in the proportion of nettle leaf flour. A similar finding was reported in pasta made from wheat, oat, and moringa leaf flour [32]. However, contradicting result was reported in noodles [33] and bread [34] made from wheat and nettle leaf flour. The finding is also contradicting the result reported for flatbread made from maize (Zea mays L.) and orange-fleshed sweet potato (Ipomoea batatas L.) flour [4], in which moisture content significantly increased with the increasing proportion of nettle flour. The moisture content of a particular product determines the microbial growth and shelf life of the product [35]. The decreased moisture content with increasing nettle flour might give longer shelf life compared to the control group.

The crude protein and fat contents were significantly decreased from $11.2 \%$ to $7.21 \%$ and 1.12 to $0.48 \%$, respectively, with an increase in the amount of nettle flour from $0 \%$ to $25 \%$. The finding is similar to another study in Ethiopia [4]. The increased crude fat with an increase in the level of nettle flour in this study is also inline, yet crude protein contradicts with another study [33]. The finding also disagrees with other studies $[29,32]$. The decreased fat and protein contents in this study might be explained by the low content of these nutrients in nettle leaf. The difference may be due to differences in recipes such that maize in this study and wheat in compared studies were used as the main recipe. The difference might also be due to variety, genotype, climate, soil, vegetative stage, harvest time, storage, processing, and treatment since these variables could affect the chemical composition of nettle $[36,37]$. The reduced fat content may be important to limit unnecessary dietary fat intake.

The total carbohydrate content was increased from $75.33 \%$ to $80.05 \%$ in the highest supplemented (SN25) flatbread. Contradicting result was recorded in noodles from wheat and nettle leaf flour [33], pasta from moringa leaf, oat, and wheat [32] in which carbohydrate content was decreased with increasing nettle leaf flour and moringa leaf flour, respectively. The present finding also disagrees with another study in which carbohydrate content did not show significant change with increasing nettle leaf flour in bread from wheat and nettle leaf flour [34]. The increase in total carbohydrate in this study might be due to the high fiber content of nettle leaf and raw material difference. The crude fiber content increased from $2.14 \%$ in control to $3.05 \%$ in the highest supplemented flatbread. A similar result was reported in other studies $[29,30,33]$.

The gross energy content of the control group and nettlesupplemented flatbread was not significantly different. This might be due to a decrease in crude protein and fat content and increased total carbohydrate with increasing nettle flour content. Thus, the reduced energy value due to decreased protein and fat content is likely compensated by increased carbohydrate content since the gross energy was coming from the three macronutrients. The result disagrees with the finding by [33], in which the gross energy was decreased ( 367.38 to $351.43 \mathrm{Kcal} / 100 \mathrm{~g}$ ) with increasing nettle leaf flour, but in line with finding by [34], in which gross energy was increased from 223.56 to $232.72 \mathrm{Kcal} / 100 \mathrm{~g}$ with increasing nettle flour leaf. A similar result was reported in pasta from oat, wheat, and moringa leaf flour where the gross energy increased from 357.00 in control to $370.64 \mathrm{Kcal} / 100 \mathrm{~g}$ by $25 \%$ moringa leaf incorporation [32].

According to the present study, the total ash content was increased from $1.84 \%$ in control to $3.81 \%$ in $25 \%$ nettle floursupplemented flatbread. Comparable results were recorded in other studies $[29,30,33]$. The high ash content of the product is indicative of the presence of high mineral contents. Similarly, the increasing total ash content with increasing nettle flour reflects the dried nettle leaf flour has a high amount of minerals than maize. There was a significant increment in the mineral content of the blend. The calcium, iron, and zinc content of nettle leaf-incorporated flatbread was nearly 5 folds, 2 folds, and 2 folds higher compared to the control group. This finding is in line with a study from Ethiopia such that calcium, zinc, and mineral content were significantly increased with the increased proportion of nettle flour in wheat flour-based nodules [33]. The result is in agreement with other findings where mineral (calcium, zinc, iron, and phosphorous) content of cookies developed from wheat and moringa leaf significantly increased with increasing ratios of moringa leaf [38]. 
The phytic acid content of flatbread was reduced by 16.7 $20.2 \%$ with the increasing proportion of nettle leaf flour from $10 \%$ to $25 \%$. However, the content showed increment within the supplemented group. The decreased in phytate content when increasing nettle flour might be due to the low proportion of maize and activation of phytase enzyme during germination. On the other hand, the increased phytate contents within nettle leaf-supplemented flatbread may be due to increased nettle leaf flour. This might need further processing such as blanching or soaking or searching for another drying method that minimizes antinutritional factor (phytate) without compromising the nutritional composition of nettle leaf. According to the international zinc consultative group suggestion, the phytate to zinc molar ratio is an important index for zinc bioavailability, and a ratio of less than 15 indicates bioavailability. A ratio of less than five has good bioavailability [28]. In the present study, the phytic acid to zinc molar ratio was decreased from 7.49 in control to 2.79 in the highest supplemented flatbread. Similarly, the phytate to iron molar ratio and phytate to calcium molar ratio significantly decreased when the proportion of nettle flour supplements was increased. This suggests that phytate:zinc, phytate: iron, and phytate: calcium molar ratio of all nettlesupplemented flatbread was below a threshold that estimates a good bioavailability of the respective minerals. The low phytate to selected mineral ratio implies bioavailability of the studied minerals (calcium, iron, and zinc) which may not be affected by the presence of phytate.

Sensory qualities such as taste, color, odor flavor, and texture are the most important feature for the formulation of a new product than quantity [39]. Thus, it is strongly believed that evaluating the sensory acceptability test of a new product is an inevitable activity besides looking at the nutritional, safety, and convenience of a given product [33]. The present study indicated that all sensory acceptability tests were decreased when increasing the proportion of nettle leaf flour. The color acceptability of flatbread was significantly $(p<0.05$ ) reduced with increasing the proportion of nettle leaf flour. The result is in agreement with other studies [29, 30, 38]. In addition to the natural color of nettle itself, research evidence recognized that drying affects sensory parameters like aroma, flavor, and appearance [40]. Drying changes the aroma of food products through losses in volatile compounds or the formation of new volatile compounds as a result of oxidation and esterification reactions [41, 42]. Hence, the reduced sensory acceptability could be explained by the change of flavor, aroma, and appearance of nettle leaf during drying. The color acceptability of the flatbread was decreased from 8.71 (liked very much) in a control group to 5.61 (neither liked nor disliked) in the highest supplemented (SN25) flatbread. Scholars illustrated that the loss of green color during drying is mainly due to the degradation of chlorophyll a and b, and carotenoid losses due to oxidation of the highly unsaturated carotenoid structure and cis-trans-isomerization during thermal processing. Hence, the color acceptability affected might be due to loss of green color by the degradation of chlorophyll and loss of carotenoids [41, 42]. The result of this finding was in agreement with [33], but contradicting with other studies $[29,32]$.

\section{Limitation of the Study}

This study did not address other antinutritional factors such as polyphenols that can affect the bioavailability of the minerals.

\section{Conclusion}

The crude protein and fat contents were decreased from 11.02 to $7.21 \mathrm{~g}$ and 1.12 to $0.48 \mathrm{mg}$ when the nettle flour supplementation increased from $0 \%$ to $25 \%$. The reduced fat content could be beneficial to limit unnecessary excess energy intake from diet and might contribute to the management of chronic diseases like obesity and overweight. On the other hand, the crude ash was increased from 1.84 to $3.81 \mathrm{~g}$; the calcium, zinc, and iron content increased from 60.51 to $283.74,1.72$ to $3.94 \mathrm{mg}$, and 5.09 to $9.24 \mathrm{mg}$ while the proportion of nettle flour supplementation increased from 0 to $25 \%$. There may also decrease mineral deficiencies and contribute to healthy life. Vitamin $\mathrm{C}$ content was very low. On the other hand, increasing nettle flour decreased crude protein and crude fat content but has no effect on gross energy. Incorporating the nettle leaf flour with maize flour compromised and reduced the sensory acceptability of flatbread.

\section{Recommendation}

Optimum baking temperature and time combination that minimizes nutrient losses should be studied. Since the sensory acceptability is compromised with the increasing amount of nettle flour, the supplementary ratio of nettle flour should be reduced to a maximum of $15 \%$. Treatments like soaking of nettle leaves with ethanol shock are recommended to increase recovery of nutrients as suggested by Maimaiti et al. [43]. On the other hand, techniques that improve organoleptic quality and sensory acceptability of stinging nettle leaf should be studied.

\section{Data Availability}

Data used for this research and analysis is available from the corresponding author and will be provided upon reasonable request.

\section{Ethical Approval}

Ethical approval was obtained from Hawassa University Ethical Review Board (ERB).

\section{Consent}

Informed written consent was obtained from sensory panelists.

\section{Disclosure}

I declare that the funding body had no role in the design of the study, the collection, analysis, and interpretation of the data, the writing of this manuscript, and the decision to submit it for publication. 


\section{Conflicts of Interest}

The authors declare that there is no conflict of interest in the finding of this study.

\section{Authors' Contributions}

Tona Z. Diddana designed the original idea and research protocol, analyzed and interpreted data, and drafted the manuscript. Gezahegn N. Kelkay revised the research protocol, is involved in data analyses, and revised the drafted manuscript. Endale E. Tescha is involved in sample preparation and data analyses and critically revised the drafted manuscript.

\section{Acknowledgments}

The authors are grateful to the Hawassa University NORAD project for funding this research work. We would also like to thank the Ethiopian Public Health Institute (EPHI) for analyzing the chemical composition of the developed product. Finally, we highly acknowledge sensory panelists. This study was conducted by getting the fund from the Hawassa University Norwegian Agency for Development Cooperation (NORAD) project.

\section{References}

[1] S. Yetneberk, M. Teamir, and A. Teklewold, "Maize based food products in Ethiopia: a review of traditional practices and research outputs," in Nutritious Maize for Ethiopia (NuME) Project, SG 2000-Ethiopia, ResearchGate.

[2] J. Mohammed, S. Seleshi, F. Nega, and M. Lee, "Revisit to Ethiopian traditional barley-based food," Journal of Ethnic Foods, vol. 3, no. 2, pp. 135-141, 2016.

[3] S. Serka, D. Getahun, and K. Abegaz, "Formulation and sensory acceptability of flat bread from kocho with broad bean (Vicia faba L.) and quality protein maize (Zea mays) flours," Journal of Food Processing \& Technology, vol. 10, no. 9, 2019.

[4] T. F. Tadesse, G. Nigusse, and H. Kurabachew, "Nutritional, microbial and sensory properties of flat-bread (kitta) prepared from blends of maize (Zea mays L.) and orange-fleshed sweet potato (Ipomoea batatas L.) flours," International Journal of Food Science and Nutrition Engineering, vol. 5, no. 1, pp. 3339, 2015.

[5] B. P. KhatiwadaS. OstiFP of the WA for SD, "Tragedy of the underutilized crops and people with changing climate: a case from Chepang Tribal Communities of Nepal," in World Sustainable Development Outlook, B. Choulagain and , Eds., pp. 327-345, Greenleaf publishing, UK, 2011.

[6] A. Maietti, P. Tedeschi, M. Catani et al., "Nutrient composition and antioxidant performances of bread-making products enriched with stinging nettle (Urtica dioica) leaves," Foods, vol. 10, no. 5, p. 938, 2021.

[7] S. Đurović, M. Vujanović, M. Radojković et al., "The functional food production: application of stinging nettle leaves and its extracts in the baking of a bread," Food Chemistry, vol. 312, article 126091, 2020.

[8] G. Moskovitz, "Herbal medicinal teas from South Africa Tés de hierbas medicinales de Sudáfrica," Blood, pp. 67-73, 2009.
[9] B. Bekele, A. Melesse, M. Beyan, and K. Berihun, "The effect of feeding stinging nettle (Urtica simensis S.) leaf meal on feed intake, growth performance and carcass characteristics of Hubbard broiler chickens," Global Journal of Science Frontier Research: D Agriculture and Veterinary, vol. 15, no. 3, pp. 120, 2015.

[10] A. Davidson and T. Jaine, The Oxford companion to food, Oxford University Press, 2006.

[11] W. Tsegaye, K. Urga, and K. Asres, "Antidiabetic activity of Samma (Urtica simensis Hochst. ex. A. Rich.) in streptozotocin-induced diabetic mice," Ethiopian Pharmaceutical Journal, vol. 27, pp. 75-82, 2008.

[12] Y. Uprety, R. C. Poudel, K. K. Shrestha et al., "Diversity of use and local knowledge of wild edible plant resources in Nepal.," Journal of Ethnobiology and Ethnomedicine, vol. 8, no. 1, p. 16, 2012.

[13] R. B. Bhat, T. Rubuluza, and A. K. Jäger, "The bio-diversity of traditional vegetables of the Transkei region in the Eastern Cape of South Africa," South African Journal of Botany, vol. 68, no. 1, pp. 94-99, 2002.

[14] F. Jimoh, A. Adedapo, A. Aliero, and A. Afolayan, "Polyphenolic and biological activities of leaves extracts of Argemone subfusiformis (Papaveraceae) and Urtica urens (Urticaceae)," Revista de Biologia Tropical, vol. 58, no. 4, pp. 1517-1531, 2010.

[15] E. A. Getachew, G. H. Desse, and G. D. Addis, "Nutritional profile of Samma (Urtica simensis Steudel) leaves grown in Ethiopia," International Journal of Science Innovations and Discoveries, vol. 3, no. 1, pp. 153-160, 2013.

[16] D. Kregiel, E. Pawlikowska, and H. Antolak, "Urtica spp.: ordinary plants with extraordinary properties," Molecules, vol. 23, no. 7, article 1664, 2018.

[17] E. Lulekal, Z. Asfaw, E. Kelbessa, and P. Van Damme, "Wild edible plants in Ethiopia: a review on their potential to combat food insecurity," Afrika focus, vol. 24, no. 2, pp. 71-122, 2011.

[18] T. T. Shonte and K. Wolde Tsadik, "Consumers' perspectives, morphological and physicochemical characteristics of stinging nettle (Urtica simensis): potentials for improved nutrition and food security," Dire Dawa, Ethiopia, 2013.

[19] R. E. Hughes, P. Ellery, T. Harry, V. Jenkins, and E. Jones, "The dietary potential of the common nettle," Journal of the Science of Food and Agriculture, vol. 31, no. 12, pp. 12791286,1980

[20] B. M. Adhikari, A. Bajracharya, and A. K. Shrestha, "Comparison of nutritional properties of stinging nettle (Urtica dioica) flour with wheat and barley flours," Food Science \& Nutrition, vol. 4, no. 1, pp. 119-124, 2016.

[21] L. K. Rutto, Y. Xu, E. Ramirez, and M. Brandt, "Mineral properties and dietary value of raw and processed stinging nettle (Urtica dioica L.)," International Journal of Food Science, vol. 2013, Article ID 857120, 9 pages, 2013.

[22] K. Pytlakowska, A. Kita, P. Janoska, M. Połowniak, and V. Kozik, "Multi-element analysis of mineral and trace elements in medicinal herbs and their infusions," Food Chemistry, vol. 135, no. 2, pp. 494-501, 2012.

[23] J. L. Guil-Guerrero, M. M. Rebolloso-Fuentes, and M. E. T. Isasa, "Fatty acids and carotenoids from stinging nettle (Urtica dioica L.)," Journal of Food Composition and Analysis, vol. 16, no. 2, pp. 111-119, 2003.

[24] N. Ioana, I. Viorica, I. Diana-Carolina, and R. Valeria, "Preliminary research regarding the therapeutic uses of Urtica 
dioica 1 note ii. The dynamics of accumulation of total phenolic compounds and ascorbic acid," Farmácia, vol. 61, no. 2, pp. 276-283, 2013.

[25] AOAC (Association of Official Analytical Chemists), Official methods of Analysis of AOAC International, vol. II, AOAC, Washington, DC, USA, 17th edition, 2000.

[26] W. O. Atwater, Principles of Nutrition and Nutritive Value of Food, Government Printing Office; 1910 (version corrected of an original issued published in 1902). US Department of Agriculture, Farmers' Bulletin, Washington, DC, 1910.

[27] I. A. Vaintraub and N. A. Lapteva, "Colorimetric determination of phytate in unpurified extracts of seeds and the products of their processing," Analytical Biochemistry, vol. 175, no. 1, pp. 227-230, 1988.

[28] K. H. Brown, J. A. Rivera, Z. Bhutta et al., "Assessment of the risk of zinc deficiency in populations and options for its control. International Zinc Nutrition Consultative Group (IZiNCG)," Food Nutrition Bulletin, vol. 25, no. 1, Supplement 2, pp. S99-203, 2004.

[29] D. R. Peryam, "Reflections," in Sensory Evaluation Celebration of Our Beginnings, pp. 21-30, ASTM, Committee E-18 on Sensory Evaluation of Materials and Products, Philadelphia, 1989.

[30] D. R. Peryam and N. F. Girardot, "Advanced taste test method," Food Engineering, vol. 24, pp. 58-61, 1952.

[31] IBM Corp, IBM SPSS Statistics for Windows, Version 20.0, IBM Corp, Armonk, NY, 2011.

[32] M. Getachew and H. Admassu, "Production of pasta from moringa leaves_oat_wheat composite flour," Cogent Food \& Agriculture, vol. 6, no. 1, article 1724062, 2020.

[33] D. Alemayehu, G. Desse, K. Abegaz, B. B. Desalegn, and D. Getahun, "Proximate, mineral composition and sensory acceptability of home made noodles from stinging nettle (Urtica simensis) leaves and wheat flour blends," International Journal of Food Science and Nutrition Engineering, vol. 6, no. 3, pp. 55-61, 2016.

[34] M. S. Maria, A. Păucean, M. S. Chiș et al., "Effect of nettle leaves powder (Urtica dioica 1.) addition on the quality of bread," Hop and Medicinal Plants, pp. 1-2, 2019.

[35] B. D. Beruk, K. Abegaz, and E. Kinfe, "Effect of blending ratio and processing technique on physicochemical composition, functional properties and sensory acceptability of quality protein maize (QPM) based complementary food," International Journal of Food Science and Nutrition Engineering, vol. 5, no. 3, pp. 121-129, 2015.

[36] I. Augspole, M. Duma, B. Ozola, and I. Cinkmanis, "Phenolic profile of fresh and frozen nettle, goutweed, dandelion and chickweed leaves," in Proceedings of the 11th Baltic Conference on Food Science and Technology "Food Science and Technology in a Changing World", Jelgava, Latvia, 2017.

[37] "Plants for a future. Earth. Plants. People," April 2018, https:// www.pfaf.org/user/DatabaseSearhResult.aspx.

[38] G. M. Tessera, H. Haile, and E. Kinfe, "Bioavailability of minerals in cookies developed from blend of moringa leaf powder and wheat flour for iron deficient lactating mothers," International Journal of Food Science and Nutrition Engineering, vol. 5, no. 6, pp. 226-232, 2015.

[39] C. K. Lutter and J. A. Rivera, "Nutritional status of infants and young children and characteristics of their diets," Journal of Nutrition, vol. 133, no. 9, pp. 2941S-2949S, 2003.
[40] T. T. Shonte and H. L. de Kock, "Descriptive sensory evaluation of cooked stinging nettle (Urtica dioica L.) leaves and leaf infusions: effect of using fresh or oven-dried leaves," South African Journal of Botany, vol. 110, pp. 167-176, 2017.

[41] M. C. Diaz-Maroto, M. S. Pérez-Coello, and M. D. Cabezudo, "Effect of drying method on the volatiles in bay leaf (Laurus nobilis L.)," Journal of Agricultural and Food Chemistry, vol. 50, no. 16, pp. 4520-4524, 2002.

[42] A. Orphanides, V. Goulas, and V. Gekas, "Effect of drying method on the phenolic content and antioxidant capacity of spearmint," Czech Journal of Food Science, vol. 31, no. 5, pp. 509-513, 2013.

[43] N. Maimaiti, N. Aili, M. K. Khan, Z. Tang, G. Jiang, and Z. Liu, "Ethanol shock enhances the recovery of anthocyanin from lowbush blueberry," Biotechnology and Bioengineering, vol. 28, no. 12, pp. 3096-3102, 2020. 